$$
\text { CONF-980708-- }
$$

Paper for ASME Pressure Vessels and Piping Conference, San Diego, California, July 26-30, 1998

\title{
EVALUATION OF T91 AFTER 130,000 HOURS IN SERVICE
}

\author{
R. W. Swindeman, V. K. Sikka, and P. J. Maziasz
}

Metals and Ceramics Division OAK RIDGE NATIONAL LABORATORY

P.O. Box 2008

Oak Ridge, TN 37831-6155

and

\author{
D. A. Canonico \\ ABB COMBUSTION ENGINEERING \\ 911 West Main Street \\ Chattanooga, TN 37402-4708
}

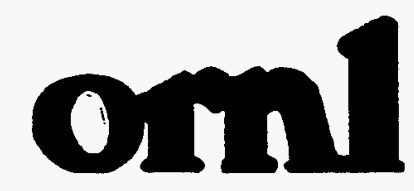

\footnotetext{
*Research sponsored by the Office of Fossil Energy, Advanced Research and Technology Development Materials Program, [DOE/FE AA 151010 0, Work Breakdown Structure Element ORNL-5(E)], U.S. Department of Energy, under contract DE-AC05-960R22464 with Lockheed Martin Energy Research Corporation.
} 


\section{DISCLAIMER}

This report was prepared as an account of work sponsored by an agency of the United States Government. Neither the United States Government nor any agency thereof, nor any of their employees, makes any warranty, express or implied, or assumes any legal liability or responsibility for the accuracy, completeness, or usefulness of any information, apparatus, product, or process disclosed, or represents that its use would not infringe privately owned rights. Reference herein to any specific commercial product, process, or service by trade name, trademark, manufacturer, or otherwise does not necessarily constitute or imply its endorsement, recommendation, or favoring by the United States Government or any agency thereof. The views and opinions of authors expressed herein do not necessarily state or reflect those of the United States Government or any agency thereof. 
EVALUATION OF T91 AFTER 130,000 HOURS IN SERVICE

\author{
R. W. Swindeman, V. K. Sikka, and P. J. Maziasz \\ Metals and Ceramics Division \\ OAK RIDGE NATIONAL LABORATORY \\ P.O. BoX 2008 \\ Oak Ridge, TN 37831-6155 \\ and \\ D. A. Canonico \\ ABB COMBUSTION ENGINEERING \\ 911 West Main Street \\ Chattanooga, TN 37402-4708
}

\begin{abstract}
Two superheater tubes fabricated from T91 were removed for evaluation after 130,000 hours service. Regions of interest included a hot section that replaced type 321 stainless steel, dissimilar welds to type 321 stainless steel safe ends, and cold bends. The evaluation consisted of metallography, transmission electron microscopy (TEM) and precipitate analysis, hardness, tensile properties, creep, and stress rupture. Observed microstructure and properties of the tubing were compared with results on unexposed and thermally aged materials. Overall, the properties were similar to expectations. Substructural coarsening occurred which produced reductions in the short-time tensile and creep strength. However, ductility remained high. Corrosion was minimal, although somewhat greater on the fire side of the cold bend. Short oxide wedge cracks were observed at the dissimilar metal welds, and type IV cracking was observed in an untempered region of a stainless steel attachment weld.
\end{abstract}

\section{INTRODUCTION}

In the early 1980's, 9Cr-1Mo-V steel tubing (T91) was installed on a trial basis in the superheaters of several power boilers. Simultaneously, laboratory aging programs were begun to determine the effects of long-time exposure on microstructure and properties. It was reported that laboratory aging at 593 and $649^{\circ} \mathrm{C}\left(1100\right.$ and $\left.1200^{\circ} \mathrm{F}\right)$ produced decreases in tensile and creep strength (Brinkman, Alexander, and Maziasz, 1990). However, no significant reductions in strength were reported for superheater tubing removed after $30,000 \mathrm{~h}$ (Ellis, Henry, and Roberts, 1990). Recently, two T91 tubes were removed after approximately 130,000 hours of service in a power boiler operating at nominal steam conditions of $552^{\circ} \mathrm{C}\left(1025^{\circ} \mathrm{F}\right)$ and $12.6 \mathrm{MPa}(1825 \mathrm{psi})$. The metal temperature was estimated to be new $593^{\circ} \mathrm{C}\left(1100^{\circ} \mathrm{F}\right)$. The sections removed contained dissimilar metal welds to 321 stainless steel at the hotter end and to T22 at the cooler end. Microstructure and mechanical properties of samples taken from the tubes were evaluated and compared to unexposed and laboratory-aged microstructures and properties.

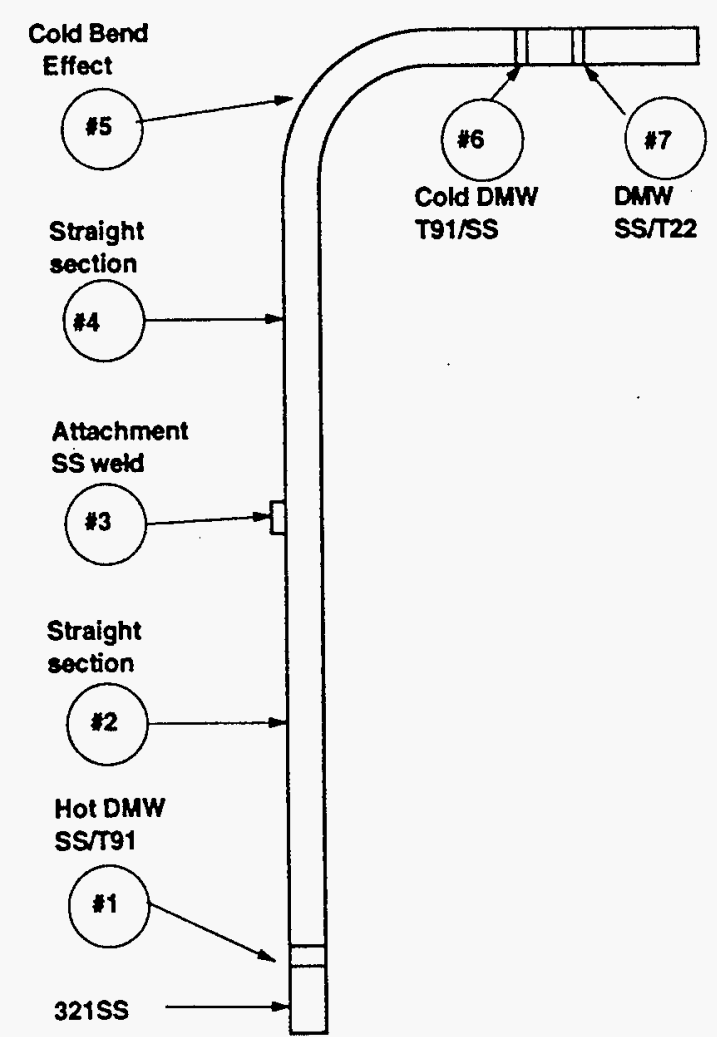

Fig. 1. Sections of a T91 superheater tube from which specimens were extracted for evauation. 


\section{MATERIALS}

The tube configuration, sketched in Fig. 1, consisted of a short horizontal run a 90 degree cold bend, and a long vertical run. The horizontal run was shop-welded to a type 321 stainless steel safe end. The type 321 stainless steel was field welded to T22. In the vertical run, one of the T91 tubes contained a chromized T91 insert piece $60-\mathrm{mm}$ long that will not be discussed here. At the end of the vertical run, the T91 was shop-welded to a type 321 stainless steel safe end. Sections removed for examination are indicated in the sketch shown in Fig. 1 and included:

\#1- a short piece in the vertical run which included a dissimilar metal weld between $\mathrm{T} 91$ and type $321 \mathrm{H}$ stainless steel; safe end

\#2- a long piece in the vertical run just above the

\#3- a short piece where a stainless steel attachment was welded to the vertical run;

\#4- a long piece below the bend;

\#5- a short piece from the bend;

\#6- a piece in the horizontal run at the dissimilar metal weld between T91 and type $321 \mathrm{H}$ stainless steel; and

\#7- a piece of the $321 \mathrm{H}$ stainless steel to P22 dissimilar metal weld.

The tubing was nominally $51-\mathrm{mm}$ diam. by $8-\mathrm{mm}$ wall ( 2 -in. diam. by 0.316 -in) and was produced by a centrifugal casting and cold pilgering operation. The chemistry of the tubing (heat XA3602) was as follows: $0.089 \% \mathrm{C}, 0.4 \% \mathrm{Mn}, 0.005 \% \mathrm{P}, 0.009 \% \mathrm{~S}, 0.19 \% \mathrm{Si}, 9.21 \%$ $\mathrm{Cr}, 0.93 \% \mathrm{Mo}, 0.197 \% \mathrm{~V}, 0.059 \% \mathrm{Nb}, 0.065 \% \mathrm{~N}, 0.05 \% \mathrm{Ni}$, $0.003 \% \mathrm{Al}$, balance $\mathrm{Fe}$. Except for $\mathrm{Si}$, which was low by $0.01 \%$, the chemistry of the tubing was within the specification for the steel.

\section{METALLOGRAPHIC EVALUATIONS}

Metallographic examination of the oxide scales was undertaken for sections $1,3,5$ and 6 , and photomicrographs are provided in Fig. 2 through Fig. 4. Generally, these scales ranged from 100 to $200 \mu \mathrm{m}$ in thickness and were similar in character to scales observed by Ellis, Henry, and Roberts (1990) in T91 after $30,000 \mathrm{~h}$. The oxide scales near the dissimilar metal weld (DMW) in Section 1 is shown in Figs. $2 \mathrm{a}$ and $2 \mathrm{~b}$ for the fireside and steamside, respectively. Typically, these scales were up to $200 \mu \mathrm{m}$ thick. On the fireside, an oxide wedge crack penetrated $200 \mu \mathrm{m}$ into the T91. On the steamside, a shallow $(100-\mu \mathrm{m}$ deep) oxide intrusion penetrated the austenitic weld metal. The fusion line and the coarse-grained heat affected zone (HAZ) of the T91 showed no metallurgical degradation relative to the base metal away from the weld. Microhardnesses ranged from HVN 270 near the fusion line to HVN 220 a distance of $6.65 \mathrm{~mm}$ from the weld.

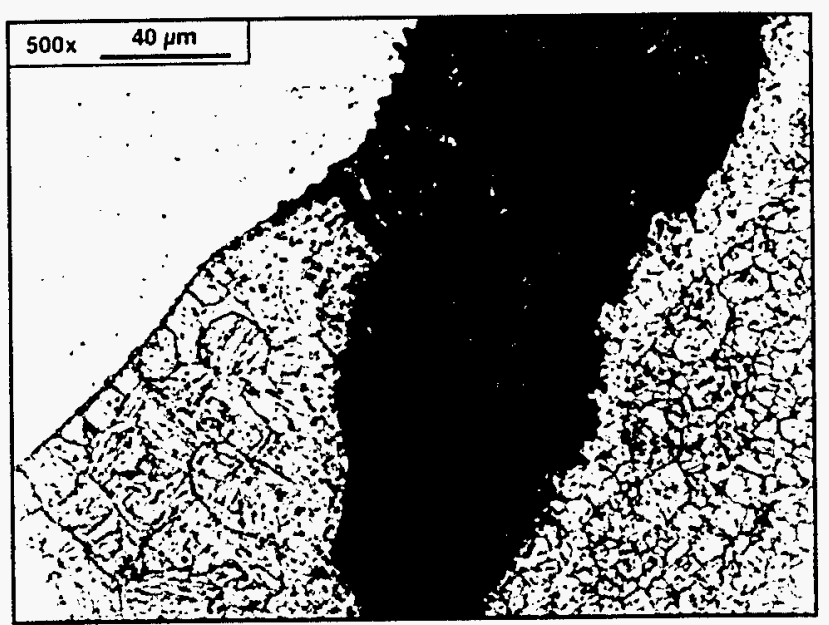

Fig. 2a. Microstructure of T91 on the fireside near the dissimilar metal weld in Section 1.

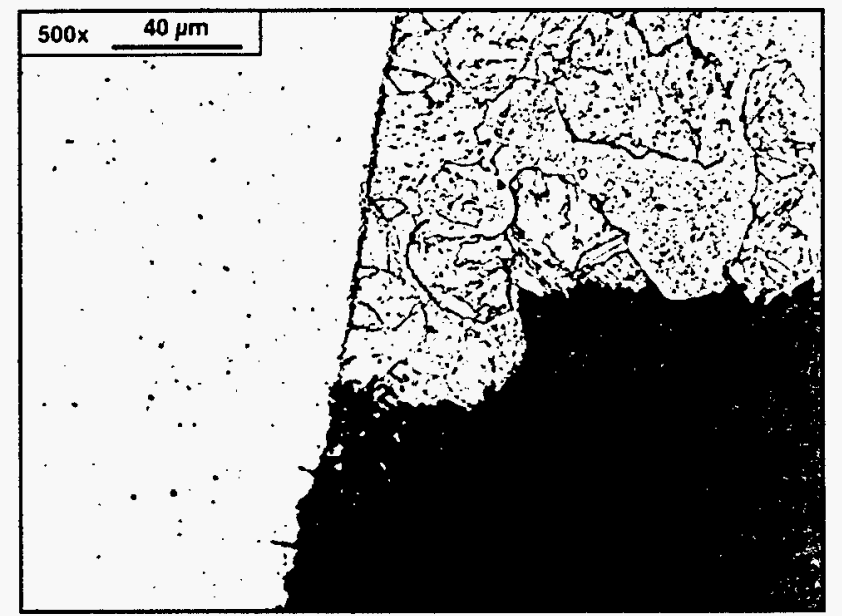

Fig. 2b. Microstructure of T91 on the steamside near the dissimilar metal weld in Section 1. 
The microstructure in the region of the stainless steel attachment (Section 3) is shown in Fig. 3. Here, cracks were observed in $\mathrm{T} 91$ that penetrated from the surface into the $\mathrm{HAZ}$ near the fusion line. The HAZ was a mixture of grain sizes and contained microcavities in the vicinity of the cracking. Microhardnesses ranged from HVN 150 near the fusion line to HVN 200 away from weld. Oxide scales on the fireside and steamside were similar to scales observed in Section 1 ( Fig. 2).

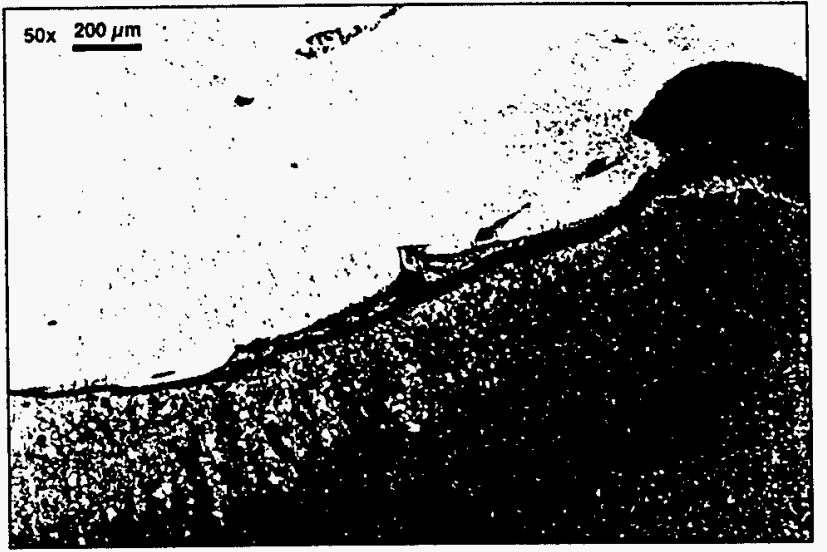

Fig. 3a. Oxide wedge cracking of T91 near an austenitic stainless steel attachment weld in Section 3.

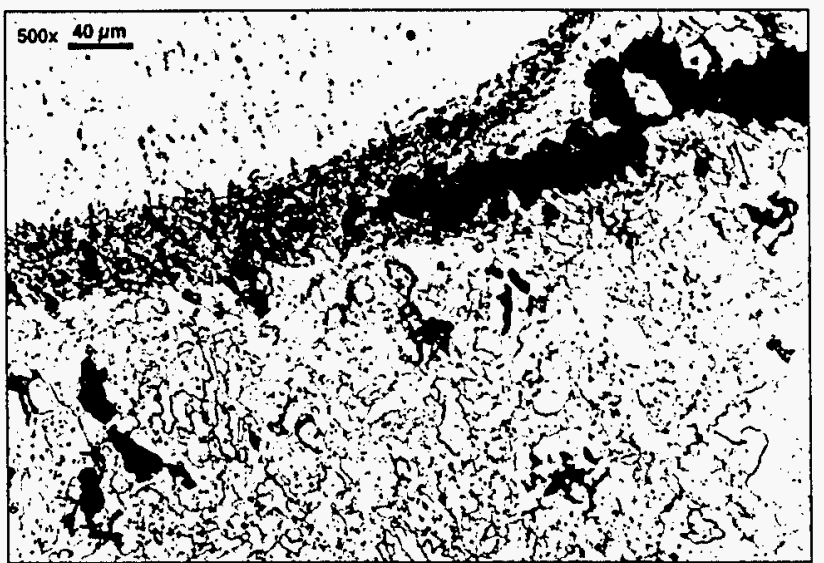

Fig. 3b. Microcavitation of T91 near an austenitic stainless steel attachment weld in Section 3.
Photomicrographs of scales in the tube bend (Section 5) are shown in Fig. 4. The scale thicknesses were similar to other scales, but the fireside scale on the extrados of the tube bend differed in character from the straight sections. Short oxide wedges were seen penetrating into the base metal (Fig. 4a). Areas of internal oxidation extended up to $100 \mu \mathrm{m}$. A few voids as large as $20 \mu \mathrm{m}$ were observed. Microhardnesses ranged from HVN 208 on the fireside to HVN 235 on the steamside.

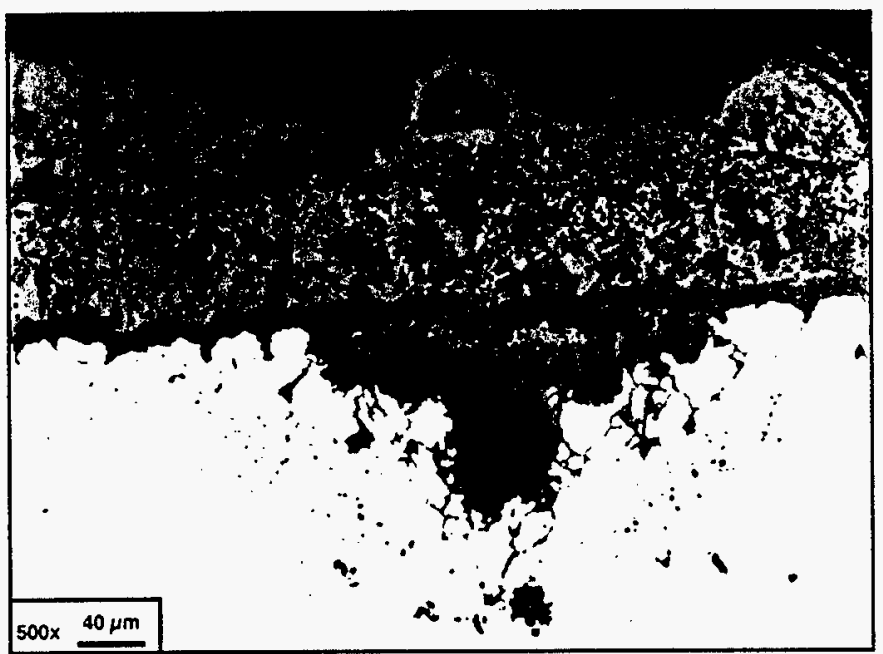

Fig. 4a. Microstructure near fireside of T91 in the cold bend of Section 5.

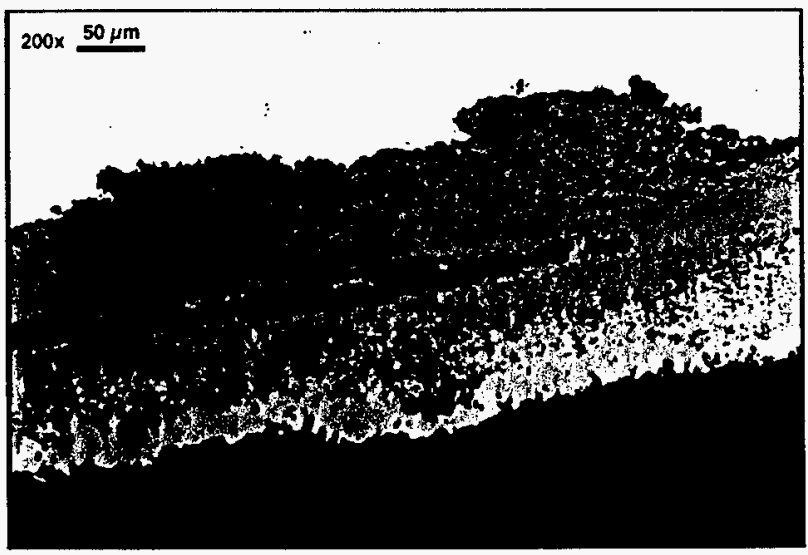

Fig. 4b. Microstructure near steamside of T91 in the cold bend of Section 5 . 
The oxide scales near the DMW to the $321 \mathrm{H}$ stainless steel safe end in Section 6 were similar to those observed in the straight section. No oxide wedges were observed nor was there any evidence of cavitation. Microhardnesses were in the range of HVN 250 near the fusion line to HVN 225 away from the weld.

\section{TENSILE PROPERTIES}

Tensile specimens were machined parallel to the longitudinal direction of the tubing of Sections 2 and 4 . These threaded-end bars contained a reduced section length of $38 \mathrm{~mm}$ (1.5 in.) with a $5.72-\mathrm{mm}(0.225$-in. $)$ diameter. Extensometers were attached on a $25-\mathrm{mm}$ ( 1 in.) length.

The tensile properties are shown in Figs. 5, 6, and 7. In Fig. 5, the yield strengths at 0.03 and $0.003 /$ minute strain rates are compared to the typical strength versus temperature curve based on a strain rate of $0.004 /$ minute for unexposed steel (Sikka, Ward, and Thomas, 1983). The yield of the exposed material at $0.003 /$ minute was less than the unexposed at all temperatures, and, except for the data at $400^{\circ} \mathrm{C}\left(752^{\circ} \mathrm{F}\right)$, yield strength values were about $90 \%$ of the unexposed values. At all temperatures the yield strengths exceeded values given in ASME Sect. II Table Y-1. Fig. 6 compares ultimate strength data. Again, the exposed material underwent a loss in strength at all testing temperatures. The strength at room temperature was reduced slightly but the strength at $650^{\circ} \mathrm{C}\left(1202^{\circ} \mathrm{F}\right)$ was about $83 \%$ of the unexposed value. Ductilities, plotted in Fig. 7, were good and gave no indication of material degradation.

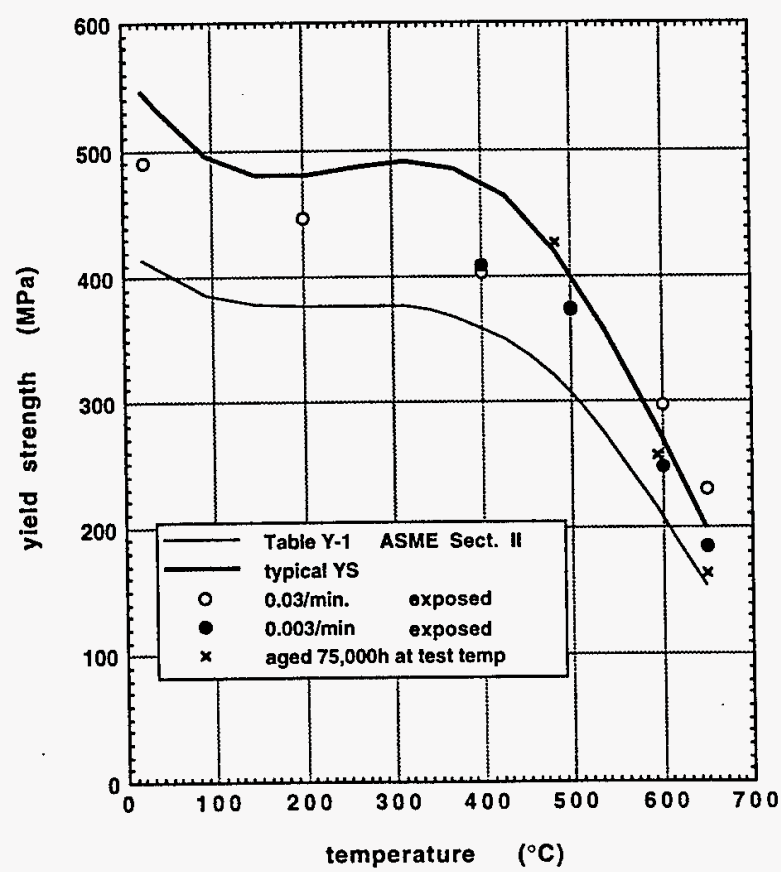

Fig. 5. Comparison of yield strength data for exposed tubing with unexposed and laboratory aged materials.

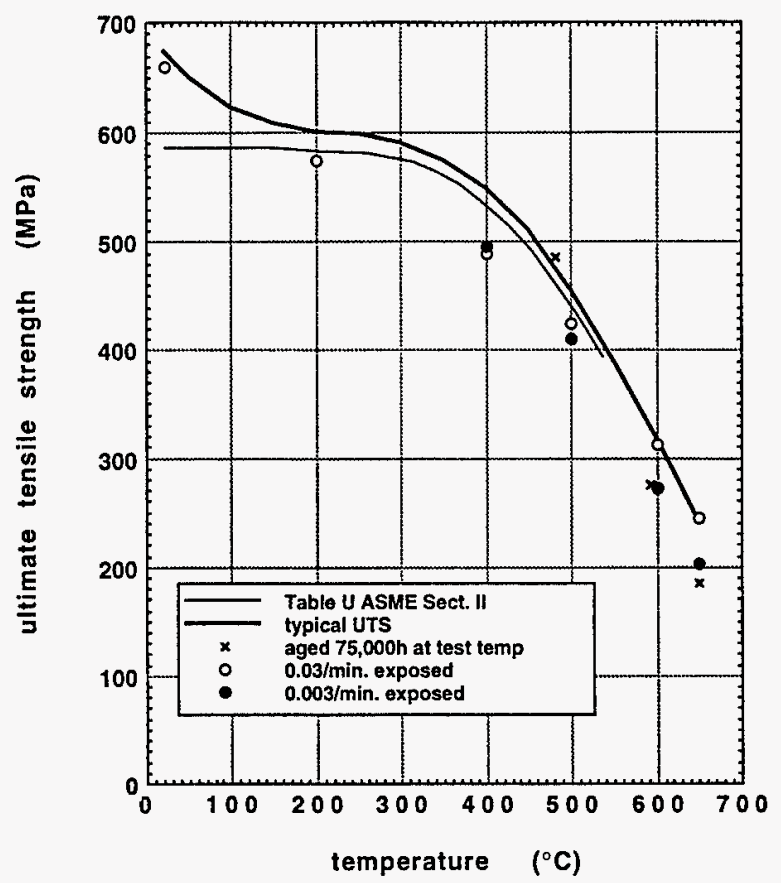

Fig. 6. Comparison of ultimate strength data for exposed tubing with unexposed and laboratory aged materials.

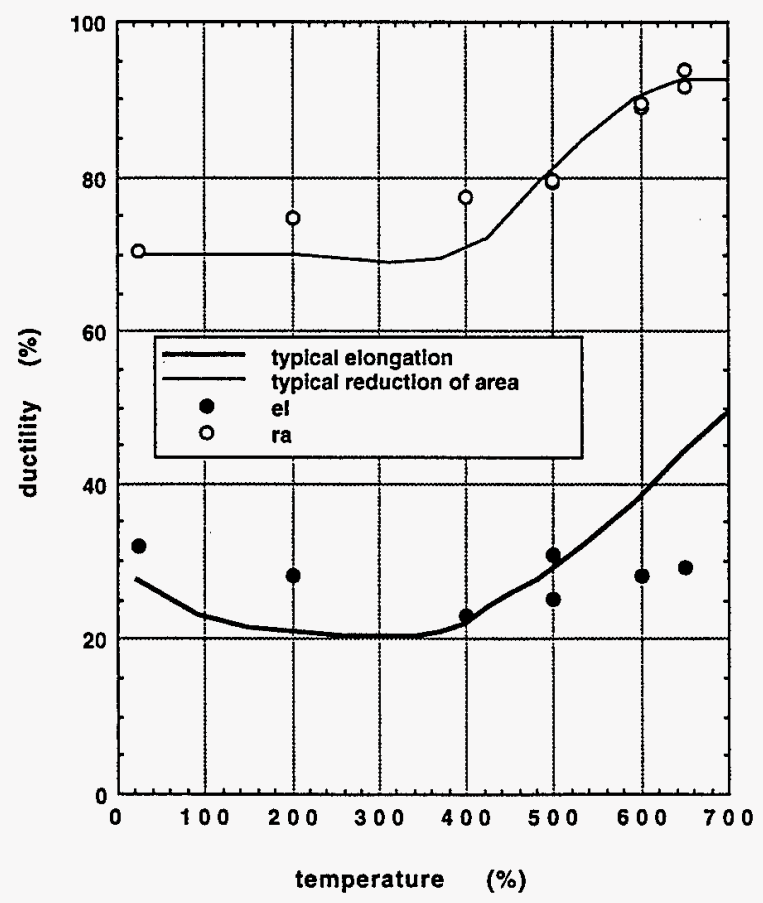

Fig. 7. Comparison of ductility data for exposed tubing with unexposed materials. 


\section{CREEP AND STRESS-RUPTURE}

Very little creep damage was expected for the conditions under which the T91 steel was operating. However, aging was expected to reduce the short-time creep and stress-rupture properties, so a series of tests was undertaken to explore the extent of service-induced aging effects and compare results with laboratory aging data. Creep tests were performed in the temperature range of 550 to $700^{\circ} \mathrm{C}$ $\left(1022\right.$ to $\left.1292^{\circ} \mathrm{F}\right)$ and stresses were chosen to permit both isostress and parametric predictions for life. In Fig. 8 the $\log$ minimum creep rate (mcr) is plotted against temperature for stresses of 100 and $140 \mathrm{MPa}$ (14.5 and $20.3 \mathrm{ksi}$ ). Comparable data are included for unexposed heat 30383. Data indicated a loss in creep strength in the exposed material as well as a change in the slope of the curve. The difference between the mcr of the exposed and unexposed steels increased with decreasing temperature or aging increasing time. Data for heat 30383 aged $10,000 \mathrm{~h}$ at $649^{\circ} \mathrm{C}\left(1202^{\circ} \mathrm{F}\right)$ are included in the plot. Assuming that the Zener-Hollomon parametric constant determined from aging studies by Brinkman, et al. (1990) was applicable to the changes in creep strength, the $10,000 \mathrm{~h}$ aging at $649^{\circ} \mathrm{C}\left(1202^{\circ} \mathrm{F}\right)$ would correspond to $150,000 \mathrm{~h}$ at $593^{\circ} \mathrm{C}\left(1100^{\circ} \mathrm{F}\right)$. At $140 \mathrm{MPa}$ (20.3 ksi), the aged mcr data fell close to the exposed material mcr data. At $100 \mathrm{MPa}(14.5 \mathrm{ksi})$, the data for aged material fell in between the mor for unexposed and exposed steels. In Fig. 9 the log rupture life data are plotted against temperature for stresses of 100 and $140 \mathrm{MPa}(14.5$ and $20.3 \mathrm{ksi})$. Again, the exposed material was weaker than the unexposed material and the slope of the log life versus temperature curve was different from the unexposed material. Another comparison of the rupture life data is provided in Fig. 10 which plots log stress versus the Larson Miller parameter.

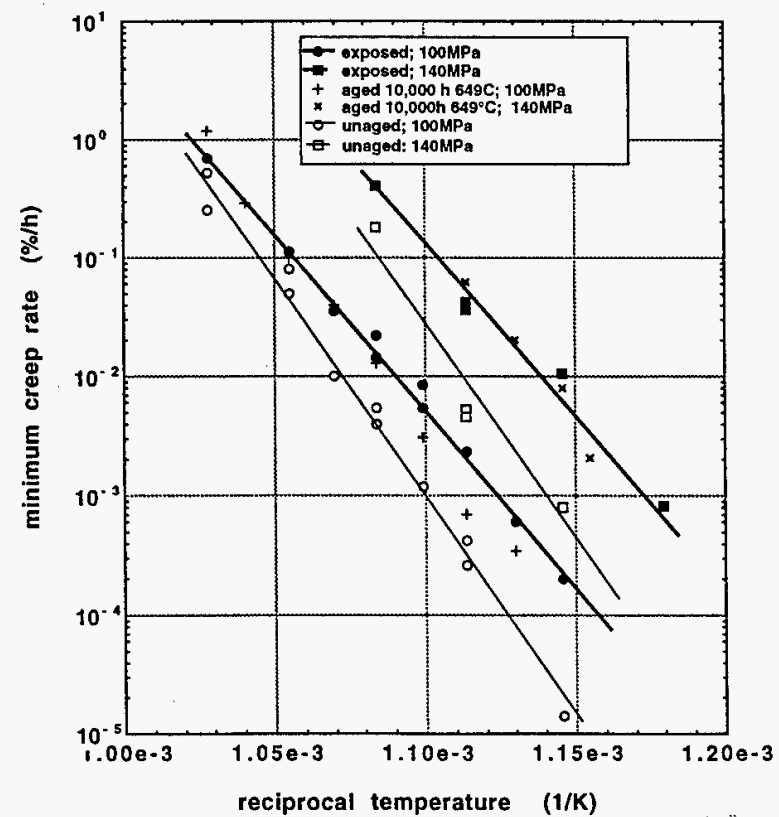

Fig. 8. Minimum creep rate versus reciprocal temperature for exposed tubing, laboratory aged material, and unexposed material.

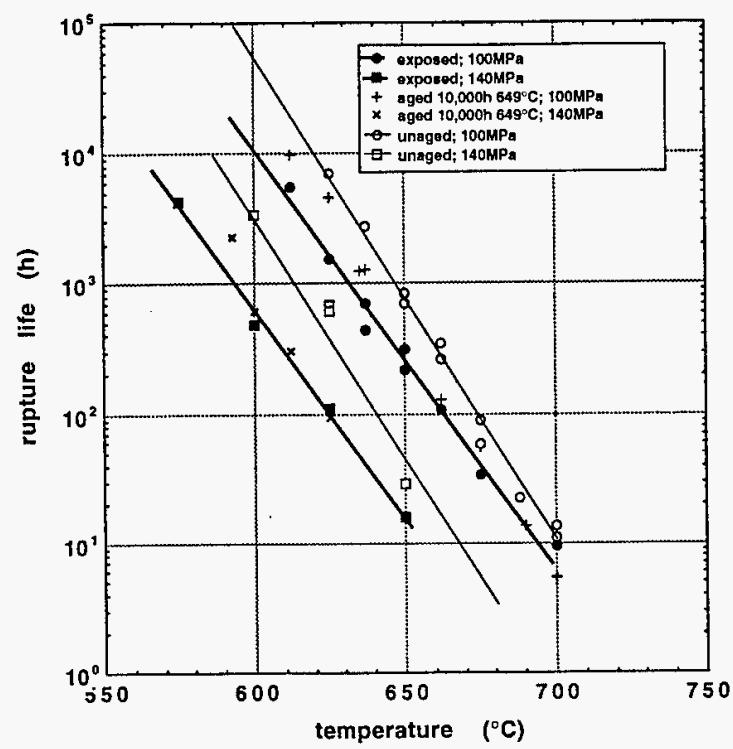

Fig. 9. Rupture life versus temperature for exposed tubing, laboratory-aged material, and unexposed material.

A parametric constant of 30 was assumed for the correlation, and the unexposed curve was produced from the stress versus 100,000 rupture life for average-strength steel. Data for two aging conditions are shown: $10,000 \mathrm{~h}$ at $649^{\circ} \mathrm{C}\left(1202^{\circ} \mathrm{F}\right)$ and $75,000 \mathrm{~h}$ at $593^{\circ} \mathrm{C}\left(1100^{\circ} \mathrm{F}\right)$. These two conditions were judged to be more-or-less equivalent to the conditions for the exposed tubing. The data for the exposed tubing fell amid the data for aged material. All data indicated that exposure reduced the strength of T 91 by $15 \%$ for the conditions that were examined. The Larson Miller curve and the data for aged and exposed materials did not extend to stresses as low as the service stress for the tubing (41MPa), so extrapolation was required to estimate life.

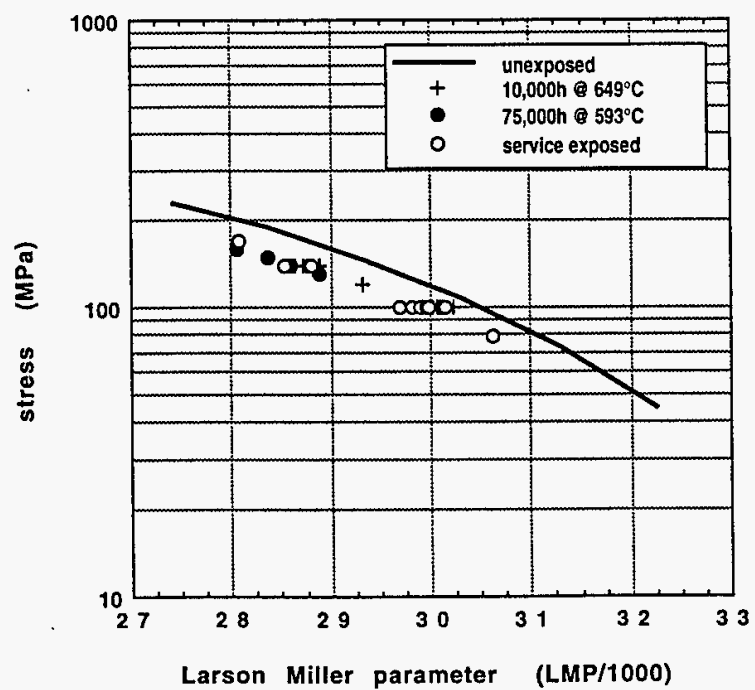

Fig. 10. Stress versus the Larson Miller parameter for exposed tubing, laboratory-aged material, and unexposed material. 


\section{CHANGES IN SUBSTRUCTURE}

Steels, such as T91, owe their creep resistance to the effects of a fine precipitation-stabilized dislocation network formed during the tempering of the martensite. Coarsening of the tempered martensite substructure due to long time service exposure results in loss of strength. Substructural changes for $\mathrm{Gr} 91$ aged to $50,000 \mathrm{~h}$ were reported by Brinkman, Alexander, and Maziasz (1990), and they observed (a) a general coarsening of substructure, (2) a reduction of dislocation density, (3) a sharpening of subgrain boundaries, (4) a coarsening of precipitates, and (5) the precipitation of Laves phase.
In the current work, changes in the precipitate and dislocation substructures in the service-exposed superheater tube were determined by transmission electron microscopy, using a Phillips CM30 (300KV) instument, and by electrotrolytic extraction of precipitate particles from the matrix to measure precipitate weight fraction. Unpublished substructure analysis of a similar $\mathrm{T} 91$ superheater tube exposed for $30,000 \mathrm{~h}$ at $540^{\circ} \mathrm{C}$ (Ellis, Henry, and Roberts, 1990) are included. Substructural evolution during service is compared to stress-free and creep-aging data from similar heats exposed up to $84,300 \mathrm{~h}$ (Brinkman, Gieseke, and Maziasz, 1993).

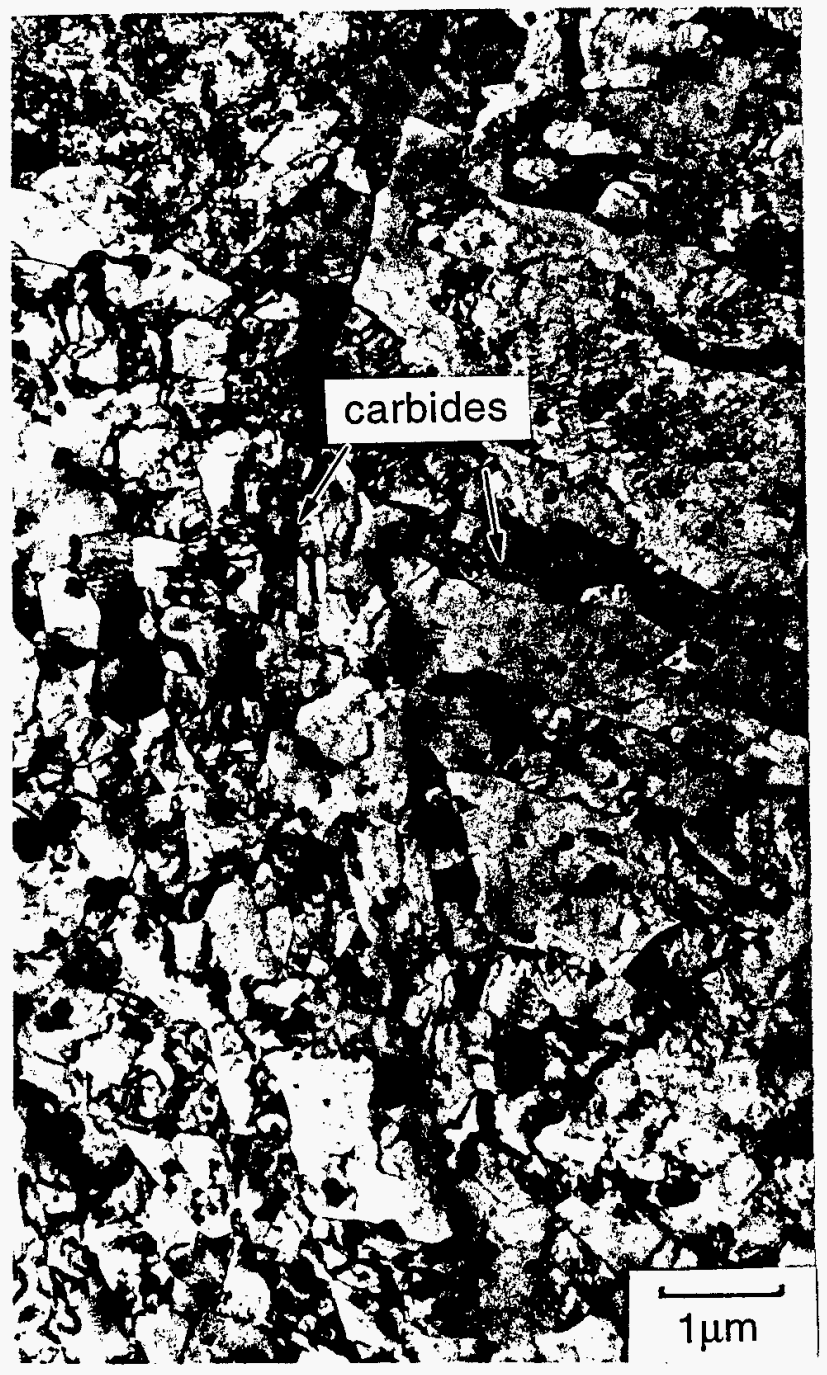

Fig. 11a. TEM of the substructure of T91 (heat XA 3602) in the as-tempered condition.

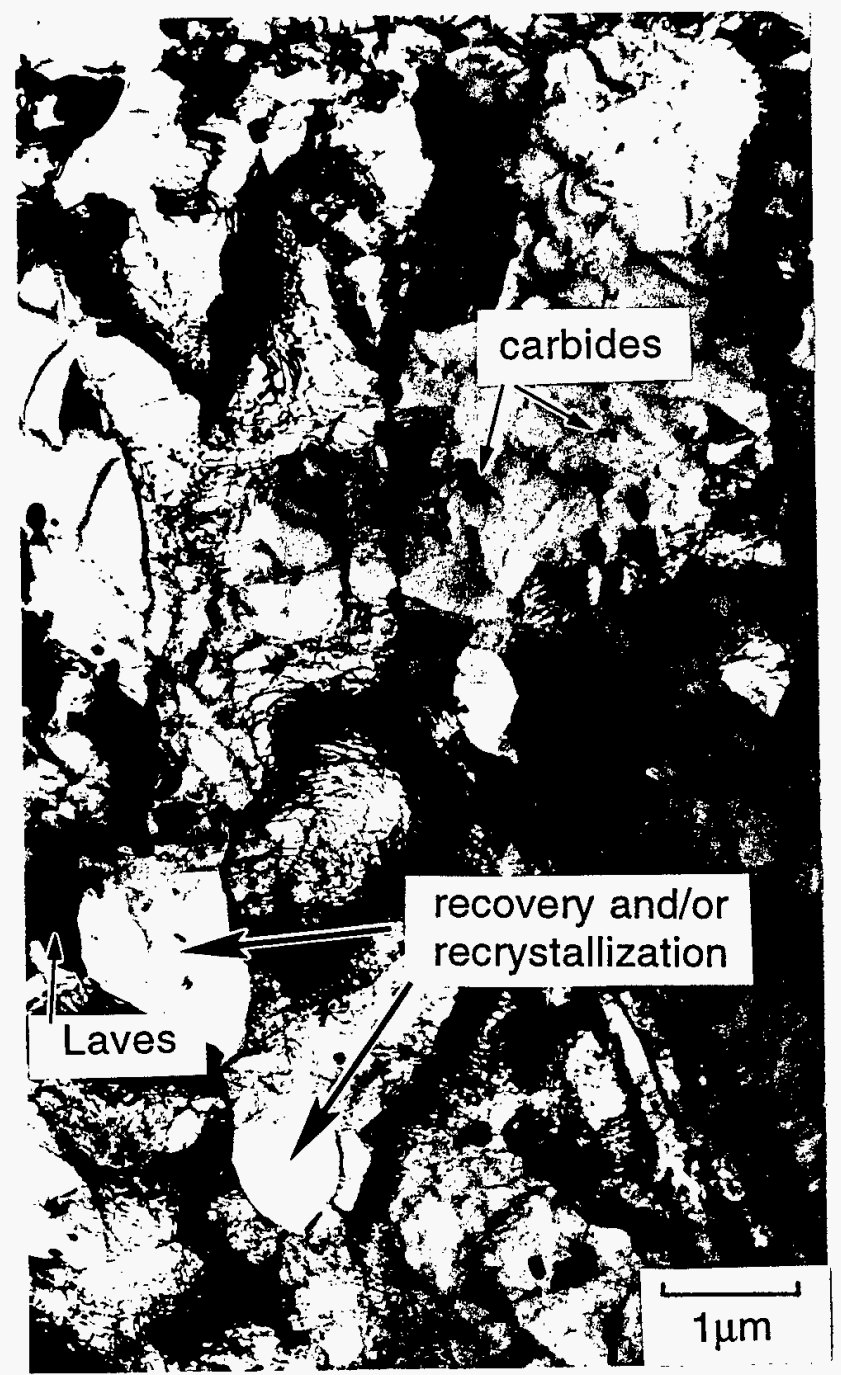

Fig. 11b. TEM of the substructure of T91 (heat XA 3602) after service for $130,000 \mathrm{~h}$ at $552^{\circ} \mathrm{C}$. 


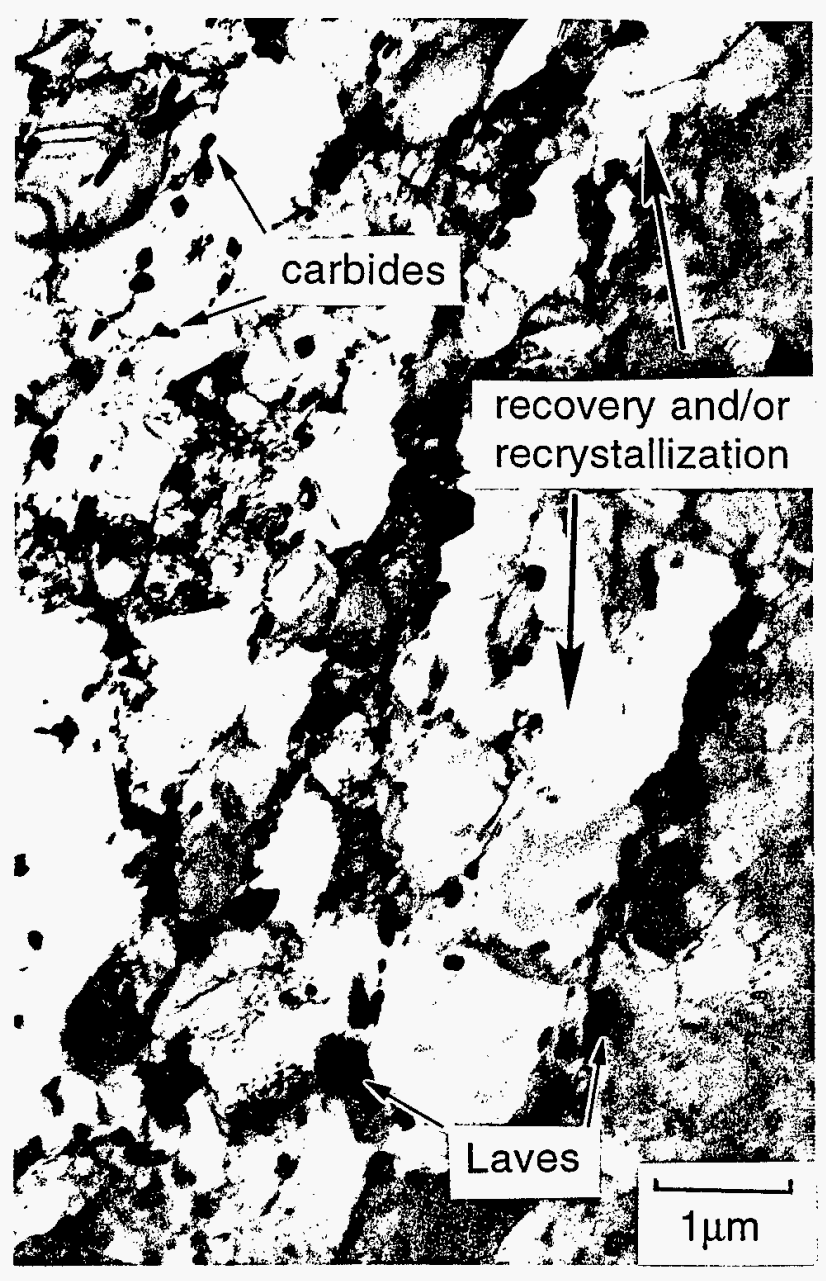

Fig. 12. TEM of the substructure of T91 (heat 30394) after creep testing for $84,300 \mathrm{~h}$ at $538^{\circ} \mathrm{C}$ and $186 \mathrm{MPa}$.

The TEM analysis of the samples service-exposed $130,000 \mathrm{~h}$ showed that significant recovery occurred relative to the fine lath substructure present in the as-tempered material (Fig. 11). However, recovery was not as pronounced as the extensive recovery and recrystallization observed in materials creep-tested for $84,300 \mathrm{~h}$ at $186 \mathrm{MPa}$ at $538^{\circ} \mathrm{C}$ (Fig. 12). The finer dislocation subboundaries that defined the astempered lath structure recovered in coarser, more equiaxed grains that were relatively free of dislocation networks. These new grains grew until they intersected the coarser astempered $\mathrm{M}_{23} \mathrm{C}_{6}$ carbides and aging-induced Laves $\left(\mathrm{Fe}_{2} \mathrm{Mo}\right.$ ) particles that comprised the precipitation substructure (Fig. 11b) The total amount of precipitation extracted from the service exposed tubing via bulk electro-etching methods was 2.8 wt percent, consistent with the development of the terminal precipitation substructure after 75,000 to $80,000 \mathrm{~h}$ at $540^{\circ} \mathrm{C}$ (Fig. 13). The as-tempered carbides $\left(\mathrm{M}_{23} \mathrm{C}_{6}\right.$ and MC) comprised 1.7 to 1.8 wt. percent of the total precipitation that occurred during aging. The behavior of the exposed tubing was similar to the isothermal aging behavior of a low silicon heat (heat 30176 with $0.11 \% \mathrm{Si}$ ), which contained less Laves phase than expected in typical composition (heat 30394 with $0.4 \%$ Si). Even after 130,000 $\mathrm{h}$ at $552^{\circ} \mathrm{C}$, the Laves phase formed as coarse particles on or adjacent to, as-tempered $\mathrm{M}_{23} \mathrm{C}_{6}$ along subgrain or prior austenitie boundaries. There was no evidence of the continuous Laves phase films observed by Alexander, Maziasz, and Brinkman (1993) after aging at $482^{\circ} \mathrm{C}$. The changes in substructure were consistent with aging-induced softening with no loss in ductility due to embrittling phases.

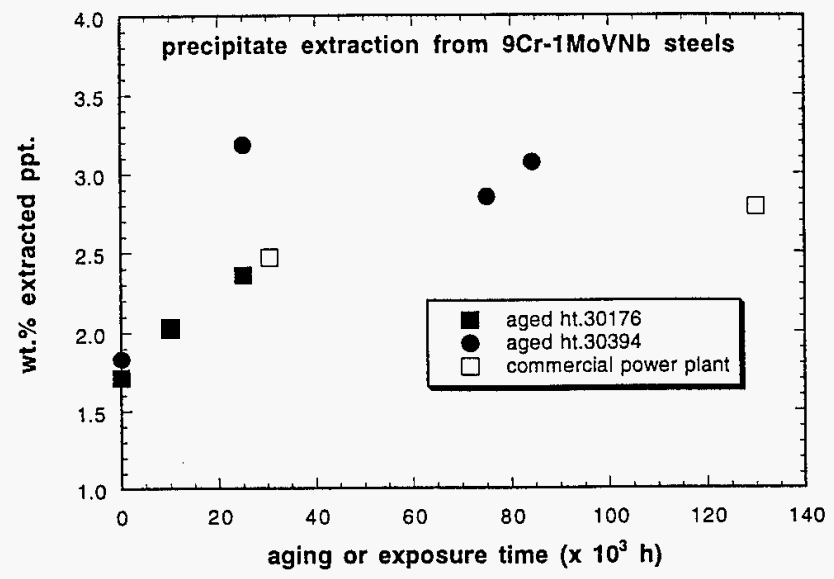

Fig. 13. Weight $\%$ of electrolytically extracted precipitates versus aging or exposure time for T91 steel. Data includes two laboratory-aged materials (heat 30176 with $0.11 \% \mathrm{Si}$ and heat 30394 with $0.4 \% \mathrm{Si}$ ) and service-exposed superheater tubing (heat 3602 with $0.2 \% \mathrm{Si}$ ) removed after 30,000 or $130,000 \mathrm{~h}$.

\section{DISCUSSION AND SUMMARY}

Overall, the experience with T91 tubing in power boilers has been excellent, and the steel appears to be a good replacement for $\mathrm{T} 22$ or 300 series stainless steels in boilers that operate to steam temperatures less than $600^{\circ} \mathrm{C}\left(1112^{\circ} \mathrm{F}\right)$. A few failures have been experienced, but those reported in the literature have been explained and appear to be related to severe operating conditions (Chang and Clark, 1997). In the tubing investigated here, a significant portion of the service exposure was to steam at $552^{\circ} \mathrm{C}\left(1025^{\circ} \mathrm{F}\right)$. Metal temperatures were estimated to be $593^{\circ} \mathrm{C}\left(1100^{\circ} \mathrm{F}\right)$. The pressure stress was relatively low (41 $\mathrm{MPa}$ or $6 \mathrm{ksi}$ ), and at this stress level the creep damage was expected to be negligible. Microstructural changes were observed, and short-time mechanical testing indicated some reduction in strength. Evaluation of longtime strength based on isostress and time-temperature parametric methods was undertaken, but the low operating stress (41 $\mathrm{MPa}$ ) of the tubing required excessive extrapolation to estimate remaining life. The service-induced damage that was observed in the tubing consisted of oxide wedges and type IV cracking under stainless steel attachment welds and local oxide penetrations to a depth of $100 \mu \mathrm{m}$ or less in cold bend of the tubing. 


\section{ACKNOWLEDGMENTS}

Several people made major contributions to the research reported here. First, E. E. Hoffman, now retired from the U. S. Department of Energy, followed the original installation of the $\mathrm{Gr} 91$ tubing and enthusiastically campaigned for the subsequent removal and evaluation. Second, N. C. Cole, retired from Oak Ridge National Laboratory, worked closely with ABB-Combustion Engineering Company and the Tennessee Valley Authority to expedite the removal and replacement of the tubing. The paper was reviewed by J. F. King who assisted in the installation of the tubing. The research was sponsored by the Office of Fossil Energy, Advanced Research and Technology Development Materials Program, [DOE/FE AA 1510100 , Work Breakdown Structure Element ORNL-5(E)], U. S. Department of Energy, Office of Fossil Energy, Advanced Research and Technology Development Materials Program, under contract DE-AC05-96OR22464 with Lockheed Martin Energy Research Corporation.

\section{REFERENCES}

Alexander, D. J., Maziasz, P. J., and Brinkman, C. R., 1993, "The Effect of Long-Term Aging on the Impact Properties of Modified 9Cr-1Mo Steel," pp. 343 to 348 in Microstructure and Mechanical Properties of Aging Materials, eds, Liaw, P. K., et al., The Mineral, Metals, and Materials Society, Warrendale, PA

Brinkman, C. R., Alexander, D. J., and Maziasz, P. J., 1990, "The Influence of Long Term Thermal Aging on the Microstructure and Mechanical Properties of Modified $9 \mathrm{Cr}$ 1 Mo Steel," pp. 107 to 115 in Microstructure and Mechanical Properties of Aging Materials, eds, Liaw, P. K., et al., The Mineral, Metals, and Materials Society, Warrendale, PA.
Brinkman, C. R., Gieseke, B., and Maziasz, P. J., 1993, "Modified 9Cr-1Mo Steel for Advanced Steam Generator Applications," 90-JPGC/NE-8, paper presented at the Joint ASME/IEEE Power Generation Conference, Boston, MA, October 21-25.

Chang, E. W. K., and Clark, R. M., 1997, "T91 Secondary Superheater Tube Failures investigation," pp. 11 to 25 in Fitness for Adverse Environments in Petroleum and Power Equipment, PVP Vol.359, American Society of Mechanical Engineers, NY.

Ellis, F. V., Henry, J. F., and Roberts, B. W., 1990, "Welding, Fabrication, and Service Experience with Modified 9Cr-1Mo Steel, pp. 55 to 63 in New Alloys for Pressure Vessels and Piping, PVP Vol. 201, American Society of Mechanical Engineers, NY.

Sikka, V. K., Ward, C. T., and Thomas, K. C., 1983, "Modified 9Cr-1Mo Steel- An Improved Alloy for Steam Generator Application," pp. 65 to 84 in Ferritic Steels for High-Temperature Applications, Proceedings of the ASM International Conference on Production, Fabrication, Properties, and Application of Ferritic Steels for High Temperature Applications, American Society for Metals, Metals Park, Ohio. 


\section{M98004944

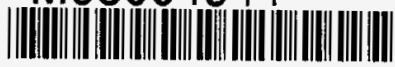

Report Number (14) ORNL/CP.-97476
CONF-980708--

Publ. Date (11) $\frac{199803}{\text { DOEIFE }}$
Sponsor Code (18) $\frac{\text { DOE }}{\text { UC-101, DOE/ER }}$
UC Category (19) 